\title{
EXTRATERRITORIALITY OF THE REGULATIONS AND INTERCONNECTIONS OF THE DERIVATIVES MARKET: LEGAL IMPLICATIONS FOR EAST AND SOUTHEAST
} ASIA $^{*}$

by

CHRISTOPHER CHEN ${ }^{* *}$

This article examines the legal implications of the interconnections of the global derivatives market, such as the exchange and over-the-counter (OTC) markets, in East and Southeast Asia. First, we introduce the interconnectedness of the global derivatives market. We then examine some legal implications of such interconnectedness from several angles, such as the extraterritoriality of relevant regulations (notably the reporting, clearing and trading mandates prescribed by the G20 and the new initial margin rule), standard product documentation, the effect of substituted compliance, the potential competition effect due to shifting OTC trades to exchange trading and the effect of consolidating exchanges and/or clearing services. We approach these issues from the perspective of Asian countries in relation to development in core markets, such as those in the US, the UK and Europe.

\section{KEY WORDS}

Derivative, Interconnection, Exchange, ISDA, Extraterritoriality, Territorial Extension, Financial Regulation

\footnotetext{
The author is grateful for the Specialized Database Funding (No. 15-C234-SDF-002) from Singapore Management University for this project.

** chchen@smu.edu.sg, Assistant Professor of Law, School of Law, Singapore Management University, Singapore.
} 


\section{INTRODUCTION}

There is probably no other market in the world that is as globally interconnected as the derivatives market. Such interconnectedness may influence laws and regulations regarding the derivatives involved. As the derivatives market, which has existed since the 1980s, is reasonably new, the high degree of interconnection also affects how norms are created or implemented in different countries. We focus on the interconnections of the global derivatives market. We also examine how the market conditions of the derivatives market affect the development of local and global regulations and consider the strategies of some Asian markets to address the potential cross-border effects of American and European regulations.

In general, a derivative is a financial instrument whose value refers to another financial instrument or underlying variable. ${ }^{1}$ Depending on the trading venue, the derivatives market can be broadly divided into two main categories: exchange-traded products and over-the-counter (OTC) transactions. Derivatives also appear in several different forms. The most fundamental instruments are options (i.e. the right to buy or sell a certain asset or variable in the future with the striking fixed at present) and forward contracts (under which one party agrees to buy and the other agrees to sell a certain asset or variable in the future with the price fixed at present). ${ }^{2}$ Standardised and exchange-traded forward contracts are generally called "futures". A "swap" is a transaction under which parties agree to exchange future flows based on benchmarks, such as the relationship between a fixed interest rate and a floating market rate (e.g. an interest rate swap ${ }^{3}$ ), a certain event (e.g. a credit default swap $^{4}$ ) and the total return of an underlying instrument (e.g. an equity swap ${ }^{5}$ ). A derivative may also be incorporated into another financial instrument (e.g. a debenture or deposit) to create a hybrid or structured product (e.g. the minibonds or structured notes that were issued to many Asian investors before the global financial crisis $^{6}$ ).

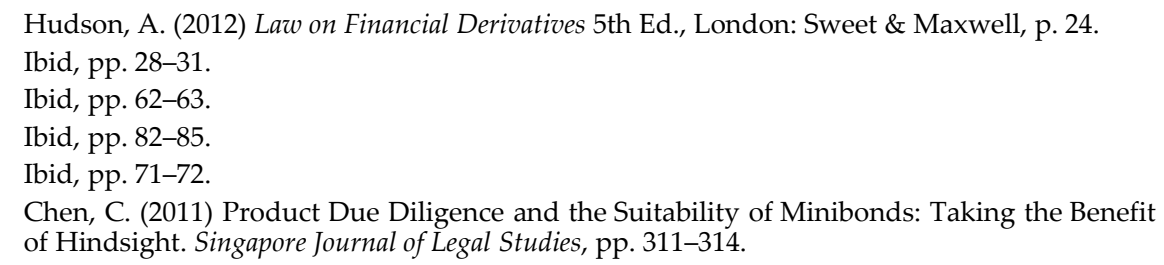


Parties often choose to settle trades in cash, although occasionally underlying assets (e.g. gold or crude oil) may be physically delivered.

A wide range of underlying variables may be involved in a derivative transaction. Underlying assets may include securities, such as shares or debentures. They may also be the prices of commodities, such as agricultural products (e.g. soybean), precious metals (e.g. iron ore) or energy (e.g. natural gas). An underlying variable may also be an index (e.g. FTSE100), a certain event (e.g. the insolvency of a bond issuer) or even the weather (e.g. a designated region's average seasonal rainfall ${ }^{7}$ ). Virtually anything that is uncertain and that fluctuates may become an underlying variable of a derivative instrument as long as there is a market for it (e.g. forward freight rate swaps for shipping rates or property derivatives for the rental of commercial buildings).

The variety of forms, trading venues and underlying variables makes derivatives and the market quite complex. As Part II below will elaborate, the derivatives market, whether exchange-traded or OTC, is very interconnected. Such interconnectedness and complexity is eventually reflected in contract and regulatory issues. We analyse the legal issues flowing from highly interconnected derivatives markets, how market interconnections affect the creation and implementation of derivative laws and regulations and the strategies adopted by Asian markets to deal with the norms implemented in the core markets.

In Part II, we examine different aspects of market interconnection in the global derivatives market. In Part III, we analyse some legal implications of the derivatives market interconnections. We then examine current legal regimes governing derivatives. Furthermore, we consider the extraterritoriality and territorial extension of US and EU regulations (i.e. regulations from core markets) and their effects on Asian markets before examining different options and the strategies Asian regulators may use in light of the current market conditions. In Part IV, we conclude this article.

\section{INTERCONNECTIONS IN THE DERIVATIVES MARKET}

The global derivatives market is highly interconnected, which is reflected in several ways. The OTC market is connected through major dealers

7 Henderson, S.K. (2010) Henderson on Derivatives 2nd Ed., London: LexisNexis, pp. 91-98. 
and standard documentation. However, the few powerful global futures exchanges, each with its own niche products and specialty, further connect traders from all over the world to participate in setting the prices of major benchmark products, thereby expanding the effects of those futures exchanges beyond their geographical locations. There may also be a connection between the OTC and exchange-traded markets.

First, the global OTC derivatives market is dominated by a few major dealers in the US, the UK and Europe (together, the "core markets"). Those dealers (e.g. Goldman Sachs, UBS or Deutsche Bank) have branches or offices in major financial centres (e.g. London, New York City, Singapore or Hong Kong) and are usually acting as counterparties to other traders. The OTC market also has clear power centres in the US and UK. Pursuant to the Bank of International Settlement's triennial central bank survey in 2016, the US led with a US\$1,241 billion daily average of all interest rate derivatives, followed by the UK (US\$1,180 billion) and France (US\$141 billion). ${ }^{8}$ The same survey in 2013 showed the UK leading with US $\$ 1,347.75$ billion, followed by the US (US $\$ 628.15$ billion), France (US $\$ 202.21$ billion) and Germany (US\$101.34 billion), which ranked second, third and fourth, respectively. ${ }^{9}$ These data show that the OTC market is dominated by the US and UK, the largest trading centres, which together share more than half of the global trading volume.

That the OTC derivatives market has two dominant power centres means that major derivatives dealers in the OTC market are located in either country. As a result, traders from outside the core markets probably have to trade with dealers from the US, the UK or continental Europe (or through their offices in the local market). This further connects the OTC derivatives market, as reflected by the financial statements of large derivatives dealers. For example, the total notional amount of derivatives traded in 2014 was US\$6,366.2 billion for JP Morgan Chase, US\$2,909.7 billion for HSBC and $€ 5,200.3$ billion for Deutsche Bank. ${ }^{10}$ In contrast, the total notional amount for the ICBC, the biggest Chinese bank, in 2014 was RMB2,529.6 billion, whereas DBS Group Holdings, which controls

\footnotetext{
8 Bank of International Settlement. (2016) Triennial Central Bank Survey of Foreign Exchange and OTC Derivatives Markets in 2016. [online] Basel: BIS. Available from: http://www.bis.org/ publ/rpfx16.htm [Accessed 6 September 2017].

9 Bank of International Settlement. (2013) Triennial Central Bank Survey - Interest Rate Derivatives Market Turnover in 2013: Preliminary Global Results. Basel: BIS, p. 1, Available from: http://www.bis.org/publ/rpfx13ir.pdf [Accessed 6 September 2017].

10 See the annual reports of JP Morgan Chase, HSBC and Deutsche Bank for the year of 2014.
} 
the biggest bank in Southeast Asia, had only approximately US $\$ 1,877$ billion in 2014. ${ }^{11}$ Although this is not a complete comparison, there are significant gaps between large banks in different regions.

Second, the interconnections in the OTC market are reinforced by the widespread use of the standard documentation issued by the International Swaps and Derivatives Association (ISDA) - that is, the ISDA master agreement and associated forms. Although with no official statistics, one estimates that approximately $90 \%$ of OTC trades are processed using the ISDA form. ${ }^{12}$ Another estimates that $85 \%$ of the collateral agreements reached in the OTC derivatives market in 2011 were based on ISDA documentation. ${ }^{13}$ Considering the overall market volume, such a high degree of standardisation in terms of contractual documentation is probably unseen in other markets.

The widespread use of the ISDA master agreement has its own historical background. In the early 1980s, when the market was growing quickly, there was strong demand for standard documentation. This provided a backdrop of the establishment of the ISDA by major derivatives dealers. ${ }^{14}$ Through these dealers, the ISDA form quickly spread to other markets. ${ }^{15}$ With market trading commonly conducted on the same contractual platform, the trading process could be more standardised to further strengthen the interconnections of the OTC derivatives market around the world.

Third, futures exchanges offer a way to examine the interconnections in the derivatives market. Although each futures exchange must be situated in a given market (e.g. Chicago Mercantile Exchange [CME] in the US), it may have a global effect, especially large futures exchanges in the US and Europe. For example, setting the price of petroleum on the wholesale or even retail level may to a certain extent depend on the prices of the West Texas Intermediate (WTI) crude oil futures traded in the CME. The prices of some precious metals (e.g. copper and palladium) may partly depend

${ }^{11}$ See the annual report of ICBC and DBS for the year of 2014.

12 Henderson, above note 7, p. 803.

13 Rauterberg, G.V. \& Verstein, A. (2013) Assessing Transnational Private Regulation of the OTC Derivatives Market: ISDA, the BBA, and the Future of Financial Reform. Virginia Journal of International Law, 54, pp. 13-14.

14 Flanagan, S.M. (2001) The Rise of a Trade Association: Group Interactions within the International Swaps and Derivatives Association. Harvard Negotiation Law Review, 6, p. 234.

15 See Gao, S. and Chen, C. (2017) Financial Transnationalism and Financial Regulation Change: a Case Study for Derivatives Markets, European Business Organisation Law Review. 
on the prices traded in the London Metal Exchange. The same also applies for many agricultural products, such as wheat and soybean.

This partly reflects the price discovery function of the futures market. ${ }^{16}$ If the price of a product in the future (e.g. the market price expected in 6 months) is known, one can determine the product's current price using the market interest rate. Through the international trade of commodities and raw materials, the price setting function of a futures exchange warrants the price of a particular futures product to affect not only local traders, but also a wide range of traders or end-users in foreign markets. For example, the movement of WTI crude oil futures would affect not only oil traders or buyers/sellers in the US, but also those outside the US who adopt the WTI crude oil futures prices as their pricing benchmark.

Sometimes, a futures exchange in one country may offer a product whose underlying variable is something in another country. For example, the Singapore Exchange (SGX) offers futures products linked to stock market performance in China and Taiwan, such as the FTSE China A50 Index Futures and the MSCI Taiwan Index Futures. ${ }^{17}$ This may further bind two or more markets together.

Cross-trading and/or cross-margining may provide a further point of interconnection between exchanges to facilitate cross-exchange trading and reduce the limitations of geography and time zones. Cross-trading may help a trader to trade the same products in different markets, often in different time zones. For example, the CME and SGX have collaborated to create an offset system for some futures or options products (e.g. Eurodollar futures) to allow market participants to continue trading at any time of day, even when one market is closed for a day. ${ }^{18}$ Some exchange operators have collaborated to create a link between two exchanges so that market participants on different continents can continue to trade in their time zones when trading sessions in the original market are

${ }^{16}$ Chen, C. (2010) Trading Risk: the Contractual Nature of Derivative Instruments and Certain Regulatory Issues, VDM Verlag Dr. Müller, p. 101.

17 Singapore Exchange. (2017) Products. [online] Singapore: SGX. Available from: http://www.sgx.com/wps/portal/sgxweb/home/products/derivatives/financials [Accessed 6 September 2017].

18 CME. (2017) CME Group Strategic Partnership with Singapore Exchange. [online] Chicago: CME. Available from: http://www.cmegroup.com/international/partnership-resources/sgxresources.html [Accessed 6 September 2017]. 
closed (e.g. the Eurex/TAIFEX $\operatorname{link}^{19}$ or Eurex/KRX link ${ }^{20}$ ). For example, a member of Eurex may continue to trade certain products after the Eurex market has closed but while the KRX market is still open, with margin and settlement transferred back to Eurex at the end of the KRX trading session. This provides traders with a seamless trading window, rather than forcing them to wait for the Eurex market to reopen the next day. Through a cross-trading link with a foreign futures exchange, an exchange in a home country (e.g. Eurex) may not have to open another exchange in a host country (e.g. South Korea), thereby reducing legal and operational costs. Its users may still enjoy extended trading hours without the need to open another trading and clearing account in the host country. Such a cross-trading link does not involve clearing services, as all trades would move back to the home exchange for clearing. Thus, there would be fewer regulatory concerns from the host state.

Some exchanges and/or clearinghouses may also allow cross-margining, which refers to an arrangement under which a trader may use the excess in his or her margin account with a broker to secure another account. Cross-margining may reduce a trader's overall need to post collateral when he or she trades in two or more different products and/or in two or more different markets. However, cross-border cross-margining is considerably more challenging than cross-trading. Instruments eligible for margining (e.g. some debentures or securities) may not be able to move seamlessly from one country to another. However, enforcing margins and collateral may also be subject to local property law, which may not be harmonised if the home and host markets have considerably different security interest laws. In addition, whether it is in the form of cash or other liquid assets, enforcement issues occur when one or more clearing service providers need to tap into the margin pool. These issues may explain why cross-margining is not very common in futures exchanges, although they may be easier to handle when cross-margining occurs between two exchanges within the same country.

\footnotetext{
19 CME. (2017) Eurex/TAIFEX Link. [online] Chicago: CME. Available from: http://www.eurex change.com/exchange-en/products/eurex-taifex-link [Accessed 6 September 2017].

20 Ibid.
} 


\section{LEGAL IMPLICATIONS: EXTRATERRITORIALITY AND THE GLOBAL FLOW OF NORMS}

The interconnectedness of the global derivatives market may affect the creation and implementation of derivative laws and regulations. We focus on the potential extraterritorial effects of core market regulations on Asian markets due to strong market interconnections, and on the solutions and strategies adopted to address these effects. First, we analyse the current status of laws governing derivatives and how they fare in light of market interconnections. Then, we address the extraterritoriality of national regulations and the need to harmonise regulatory rules, and discuss some concerns over global competition in exchanges and clearing service providers.

\subsection{CURRENT STATUS OF LAWS GOVERNING DERIVATIVES: INTERNATIONAL AND DOMESTIC DIMENSIONS}

The development of derivative laws reflects the interconnectedness of the global derivatives market. On the private law side, a distinct feature of the global OTC derivatives market is the adoption of the ISDA master agreement as the standard form regulating a super-majority of global trades. In addition, English law or New York law is the default governing law of the agreement. As English law and New York law are largely within the common law family, the governing contractual norms of OTC derivatives are quite uniform. The same business model (i.e. standardised contracts traded on exchanges before moving to clearinghouses for clearing and settlement, supported by margin requirements and membership agreements ${ }^{21}$ is used in almost every futures exchange in the world. ${ }^{22}$

On the regulatory side, there were interrelated regulatory regimes at the international level after the global financial crisis. Regarding OTC derivatives, radical reforms have been implemented in the past few years. Before the global financial crisis, OTC derivatives were commonly seen as falling into the "no man's land" of the overall regulatory system, ${ }^{23}$ with no dedicated regulations. Regulators could indirectly regulate derivatives

\footnotetext{
${ }^{21}$ Braithwaite, J. P. (2016) The Dilemma of Client Clearing in the OTC Derivatives Markets. European Business Organisation Law Review, 17, p. 356.

22 For the life cycle of a typical futures contract, see Chen, above note 16, pp. 79-99.

${ }^{23}$ Cohen, S. S. (1995) Financial Services Regulation: a Mid-Decade Review: Colloquium: the Challenge of Derivatives. Fordham Law Review, 63, p. 2013.
} 
trading through existing banking or insurance regulations. ${ }^{24}$ The situation changed radically after the collapse of Lehman Brothers. During the Pittsburgh Summit in 2009, the G20 declared a commitment to strengthening the international financial regulatory system, such as by pushing standardised OTC derivatives to be traded on exchanges or electronic trading platforms and to be cleared through central counterparties, and to improving transparency by prescribing the reporting of OTC trades to trade repositories. ${ }^{25}$ In short, there are three main regulatory mandates on OTC derivatives: trade reporting, clearing and exchange trading. These mandates are meant to control counterparty risk, to improve transparency and to prevent systemic risk via the derivatives market.

With international regulators aiming to divert at least some OTC trades to organised exchanges or trading platforms and to be cleared by central counterparties, global regulatory reforms provide further interconnections between the OTC and exchange markets. More trades must be accommodated to improve the regulatory system for central counterparties (CCPs) and trading platforms. For example, CCPs must have solid solvency requirements to prevent them from becoming mammoth financial institutions that are too big to fail. ${ }^{26}$ With more trades expected to enter trading and clearing systems, associated issues will arise, such as the fairness of market access, pricing and competition or the protection of customer information and client money. ${ }^{27}$

${ }^{24}$ For example, under Singapore law, an insurer can only trade derivatives "for the purposes of hedging or efficient portfolio management". Investment of Insurers, Notice 125. Republic of Singapore. Singapore: MAS. In English.

25 G 20. (2009) Leaders' Statement - the Pittsburgh Summit. [online] Available from: http://ec. europa.eu/archives/commission_2010-2014/president/pdf/statement_20090826_en_2.pdf [Accessed 6 September 2017].

26 See generally Roe, MJ (2013) Clearinghouse Overconfidence. California Law Review, 101, pp. 1641-1703; Yadav, Y. (2013) The Problematic Case of Clearinghouses in Complex Markets. Georgetown Law Journal, 101, pp. 387-444; Chamorro-Courtland, C. (2012) The Trillion Dollar Question: Can a Central Bank Bail Out a Central Counterparty Clearing House Which Is "Too Big to Fail"? Brook Journal of Corporate, Financial \& Commercial Law, 6, p. 433; Kress, JC. (2011) Credit Default Swaps, Clearinghouses, and Systemic Risk: What Centralised Counterparties Must Have Access to Central Bank Liquidity? Harvard Journal on Legislation, 48, pp. 49-93; Nichol, A. (2013) Hedging against the Next Financial Crisis: Proposals for Managing Systemic Risk in Centrally Cleared Derivatives Transactions. Banking and Finance Law Review, 29, pp. 169-184; Wendt, F. (2015) Central Counterparties: Addressing their Too Important to Fail Nature. [online] IMF. Available from: https://www.imf. org/external/pubs/ft/wp/2015/wp1521.pdf [Accessed 6 September 2017].

27 See generally Greenberger, M. (2013) Diversifying Clearinghouse Ownership in Order to Safeguard Free and Open Access to the Derivatives Clearing Market. Fordham Journal of Corporate \& Financial Law, 18, pp. 245-268. 
However, the power imbalance in OTC derivatives has remained unchanged since the global financial crisis. The market for exchange-traded derivatives and derivatives clearing is still dominated by a few of the largest Western exchange operators and CCPs. For example, in 2017, CCPs clearing in multiple popular currencies (i.e. US dollars, pounds, euros and Japanese yen) can only be found in three financial centres (i.e. London, Chicago and New York). ${ }^{28}$ Thus, new regulatory reforms may create further issues if trades from all over the world are cleared in a handful of CCPs situated in a few countries.

A competition effect may also exist. The cross-border merger and acquisition of futures exchanges and CCPs (especially across the Atlantic) amidst EU reforms to break up the "vertical silo" model ${ }^{29}$ may further affect how the market evolves. In other words, current regulatory reforms seem to favour incumbent exchange operators and CCPs in the West by prescribing trade reporting, clearing and trading mandates. As we argue in the following, this may further strengthen the market power of Western traders, making it more difficult for other markets to catch up.

Next, we consider the extraterritoriality of laws coming from the interconnections of the global derivatives market. We then address some competition effects and the effect of harmonising regulatory rules at the international stage on Asian regulators when designing regulatory rules in light of the market dominance and interconnections in the global derivatives market.

\subsection{EXTRATERRITORIALITY OF REGULATIONS AND SUBSTITUTED COMPLIANCE}

As discussed previously, one prominent feature of the global derivatives market is that there are two clear power centres: the US and UK. The major dealers from these centres dominate the markets. The US market is regulated by US federal and state regulations and the UK market is governed by UK regulations (and henceforth influenced by EU regulations at least until the conclusion of Brexit), which creates two tiers of legal interactions. One question concerns the coherence of US and EU

28 Stafford P. (2016) US Eyes Prize in Brexit Battle Over Derivatives. Financial Times, 20 October. Available from: https://www.ft.com/content/8ae3e610-908b-11e6-a72e-b428cb934 b78 [Accessed 6 September 2017].

29 See Financial Times. (2008) Clearing the Way. 17 April. Available from: https://next.ft.com/ content/135b1744-0be2-11dd-9840-0000779fd2ac [Accessed 6 September 2017]. 
regulations. As both sides of the Atlantic have large derivatives dealers, a conflict of regulations between EU and the US may affect the operation of the market. This is much less an issue on the private law side, as the ISDA master agreement generally adopts either New York law or English law, which both share common law heritage, as the governing law. However, there may be conflicts regarding the regulations or relevant rules. For example, whether the level of the initial margin or variation margin for non-cleared derivatives differs significantly in the US and the EU may create room for regulatory arbitrage and impose considerable compliance costs on firms trading on both sides of the Atlantic. ${ }^{30}$

Another question concerns how US and/or EU/UK law affect other countries (e.g. Asian financial markets) when dealers trade in the main markets or with dealers from the US or Europe. This raises concerns over the extraterritoriality of US and/or EU law. As the laws governing major markets may affect traders and trading activities in other markets, the problem of the extraterritorial application of domestic regulations arises. This further prompts calls for the harmonisation of regulatory rules, at least between the two giants, through international law, soft law or other mechanisms. This is further discussed in Section C.

As a result, regulators from non-US and non-EU markets may have to look to the two giants to determine how regulations develop and evolve. For example, regulators in Hong Kong and Singapore, the largest financial centres in Asia Pacific, have to look to regulations in not only the US, but also the EU for clues, as traders in the two markets are either branches of American, European or British financial institutions or have to trade with major market dealers in the West. ${ }^{31}$ Thus, regulatory developments

30 The US and the EU eventually reached an agreement in 2016 regarding the margin rule for non-cleared derivatives. See Brunsden, J. and Stafford, P. (2016) EU and US Strike Derivatives Regulation Deal. Financial Times, 11 February. Available from: https://www.ft. com/content/b7f72eda-cfef-11e5-92a1-c5e23ef99c77 [Accessed 6 September 2017].

31 For example, in both Hong Kong and Singapore, early consultation papers on derivatives regulations all compare the developments in the US and EU and in Japan and Australia. See Hong Kong Securities and Futures Commission. (2011) Consultation Paper on the Proposed Regulatory Regime for the Over-the-Counter Derivatives Market in Hong Kong. Hong Kong: SFC. Available from: http://www.sfc.hk/edistributionWeb/gateway/EN/consultation/doc?refNo= 11CP6 [Accessed 6 September 2017]; Monetary Authority of Singapore. (2012) Proposed Regulation of OTC Derivatives. P003-2012. Singapore: MAS. Available from: http://www.mas. gov.sg/News-and-Publications/Consultation-Paper/2012/Consultation-Paper-on-ProposedRegulation-of-OTC-Derivatives.aspx [Accessed 6 September 2017]. 
in the two major markets have immense effects on other markets, indirectly affecting regulatory design, a point we elaborate as follows.

Before advancing further, we must consider the meaning of extraterritoriality. There has been some debate on the boundary between extraterritoriality and mere territorial extension. ${ }^{32}$ Professor Joanne Scott defines extraterritoriality as

"the application of a measure triggered by something other than a territorial connection with the regulating state". ${ }^{33}$

In contrast, territorial extension occurs when

"the application of a measure is triggered by a territorial connection but in applying the measure the regulator is required, as a matter of law, to take into account conduct or circumstances abroad". ${ }^{34}$

In the derivatives market, both effects have occurred.

\subsubsection{TERRITORIAL EXTENSION OF US AND EU REGULATIONS}

Both US law and EU law try to define the territorial extension of derivatives regulations by assuming jurisdiction over transactions conducted by home institutions. Essentially, a foreigner is regulated by American and/or European regulations he or she conducts a regulated activity in either market. For example, in the UK, dealing in investments, which includes securities and other contract-based investments (e.g. derivatives), as a principal party or an agent is a regulated activity that requires authorisation from the UK's financial regulator. ${ }^{35}$

However, the scope of OTC derivatives regulations may be considerably wider. The clearing mandate demonstrates the differences in the jurisdictional scope of US and EU regulations.

In the US, the Dodd-Frank Wall Street Reform and Consumer Protection Act $(\mathrm{DFA})^{36}$ regulates activities that

\footnotetext{
32 Scott, J. (2014) Extraterritoriality and Territorial Extension of EU Law. American Journal of Comparative Law, 62, pp. 89-90.

33 Ibid, p. 90.

34 Ibid.

35 See Financial Services and Markets Act 2000 (c. 8) ss. 19 and Schedule 2, para. 2. United Kingdom of Great Britain and Northern Ireland. London: HMSO. In English.

36 Dodd-Frank Wall Street Reform and Consumer Protection Act (Pub. L. 111-203) s 723(h)(1), 12 USC 2(h)(1). United States of America. Washington: Government Publishing Office. In English.
} 
"... have a direct and significant connection with activities in, or effect on, commerce of the United States (emphasis added)". ${ }^{37}$

In its subsidiary rule, the Commodity Futures Trading Commission focuses on the term "US person". One's activities are governed by the DFA if he or she is a US person, which is widely defined to include any natural person who is a resident of the US, any legal entity (e.g. companies and partnerships) organised in or having its principal place of business in the US, any trust governed by US law, any collective investment vehicle organised under US law (except for those offered only to non-US persons) and any legal entity that is majority-owned by the aforementioned persons. ${ }^{38}$

In contrast, in Europe, the European Market Infrastructure Regulation $(E M I R)^{39}$ requires a trade to be cleared by a CCP subject to EU law if it is concluded between two European parties who are financial counterparties or non-financial counterparties that meet the clearing threshold. ${ }^{40}$ When both parties are from outside the EU, a trade is subject to European regulation if the contract has a "direct, substantial and foreseeable effect" in the EU or when it is necessary and appropriate. ${ }^{41}$ A further delegated regulation clarifies that such a direct, substantial and foreseeable effect means that a trade is guaranteed by an institution within the EU if the guarantee is above a certain amount. ${ }^{42}$ This means that a totally foreign transaction would trigger European regulation if there were some financial effect in the EU.

In short, the US extends its reach to certain foreign financial institutions through their connections with the US. In contrast, EU law emphasises

\footnotetext{
7 USC 2(i).

38 Interpretative Guidance and Policy Statement Regarding Compliance with Certain Swap Regulations, 78 FR 45292, 45316-45317. United States of America. Commodities Futures Trading Commission. Washington: CFTC. In English.

39 Regulation (EU) No. 648/2012 of the European Parliament and of the Council of 4 July 2012 on OTC Derivatives, Central Counterparties and Trade Repositories. Office Journal of the European Union (OJ. L. 201). 27 July. Available from: http://eur-lex.europa.eu/legalcontent/EN/TXT/?uri=celex\%3A32012R0648 [Accessed 6 September 2017]. ("EMIR")

40 Ibid, Recital 13 and arts. 4(1)(a)(i) to (iii).

${ }^{41}$ Ibid, art. 4(1)(a)(v).

42 Commission Delegated Regulation (EU) No. 285/2014 of 13 February 2012 supplementing Regulation (EU) No. 648/2012 of the European Parliament and of the Council with regard to regulatory technical standards on direct, substantial and foreseeable effect of contracts within the Union and to prevent the evasion of rules and obligations. Recital 5. Office Journal of the European Union (L85/1) 12 March. Available from: http://eur-lex.europa.eu/Lex UriServ/LexUriServ.do?uri=OJ:L:2014:085:0001:0003:EN:PDF [Accessed 6 September 2017].
} 
financial effects on the market. Although there are some common features in extending regulations' territorial jurisdictions to financial institutions in the home market, the focuses of the two markets differ in certain ways. US regulations focus more on a trader's identity. In other words, the territorial extension of the DFA is built upon the person. Thus, if a trade is purely between two foreign parties and has no effect on the US market, it may still fall under US regulation if one party is considered a US person, whose definition is wide enough to capture some foreigners. In contrast, EU regulations seem to be more reserved, as they extend the application of the EMIR only to overseas transactions that have significant financial effects on the EU market if conducted purely between two non-EU persons.

This poses a challenge for financial regulators in Asia. Asian regulators are unlikely to have the luxury of imposing stringent regulations and wide territorial extensions of OTC derivatives regulations. A wide jurisdictional scope may push many transactions offshore. Systemic risk may increase if there is insufficient liquidity to reduce the credit risk facing local CCPs. As one essential tool to protect a CCP from a large insolvency or default is to offset contrary trades committed by the same trader, the market needs to have sufficient liquidity for people to conduct trading and to have a sufficient number of opposing trades. This explains why Hong Kong and Singapore require trades to have some degrees of local connection to trigger the mandatory reporting obligation for OTC derivatives, through either physical connections (e.g. the residence of the person who makes the trade) or effects (e.g. a trade booked in the account of a Hong Kong subsidiary). ${ }^{43}$ On the one hand, the rule ensures that regulators can still govern trades that have some local impact. On the other, by limiting the jurisdiction scope of regulation, it would not have the consequence of driving foreign traders away as long as the local market can run an equivalent regulatory system to that in the EU and/or US.

There is no doubt that the major financial centres in Asia want a share of OTC derivatives trading and clearing. A certain degree of regulatory competition may therefore take place. As both markets thrive as international financial centres, there are a lot of foreign traders trading

Securities and Futures (Reporting of Derivatives Contracts) Regulations 2013 (No.S 668), regulation 2(1). Republic of Singapore. Singapore: MAS. In English. ("Singapore Reporting Rules"); Securities and Futures (OTC Derivative Transactions - Reporting and Record Keeping Obligations) Rules (Cap 571AL), rule 4(1). Hong Kong Special Administrative Region of the People's Republic of China. Hong Kong: SFC. In English. ("HK Reporting Rules") 
in either market. From this light, Singapore and Hong Kong's positions should be sensible to not scare away foreign traders while maintaining control of the trades that have local connections and effects.

\subsubsection{EXTRATERRITORIAL EFFECT OF REGULATION}

US and EU regulations may have considerable extraterritorial effects in other parts of the world. The underlying problem is that at least two parties are required to make a trade. Therefore, even if a party has no connection to a country (e.g. the US), it may be subject to the national law of that country through the nature of the counterparty or through another indirect connection to that country. Implementing reporting and clearing mandates for OTC derivatives may exacerbate the problem of extraterritoriality through a wide jurisdictional scope, as described in the previous section.

Such extraterritoriality may affect non-US and non-EU market countries or market participants (e.g. Singapore or Hong Kong). First, a transaction conducted completely overseas may still be subject to US and/or EU regulations. For example, a Japanese trader may be forced to submit a trade to a US-based trade repository for reporting and/or a US-based CCP for clearing if the trader deals with a US bank. In this case, the transaction falls within the jurisdictional scope of US regulations due to the nature of the counterparty. Although the Japanese trader is not a US person, they may be forced to report and clear the trade in the US unless the US bank allows for reporting and clearing of the trade to or by a foreign repository or CCP, raising the issue of foreign system recognition and substituted compliance (discussed below). This also means that the Japanese trader may incur additional compliance costs if the same trade has to be reported twice (once to the US and another time subject to Japanese law). In short, the extraterritorial effects of US and EU law may enhance the legal risks and compliance costs of foreign financial institutions. The effects may worsen if the US and EU continue to clash over CCP regulatory issues. ${ }^{44}$

Second, regarding the trade reporting of OTC derivatives, such extraterritoriality may affect information flow. Regulators outside of the US

44 Chon G. (2014) Massad See End to US-EU Clearing Disputes. Financial Times, 31 July. Available from: http://www.ft.com/cms/s/0/c0a04f92-18c3-11e4-a51a-00144feabdc0. Html\# axzz3PQyKFc50 [Accessed 6 September 2017]; Stafford P. (2014) Quick View: Clearing up Differences. Financial Times, 16 June. Available from: http://www.ft.com/cms/s/0/3ccba18af52d-11e3-91a8-00144feabdc0.html\#axzz3PQyKFc50 [Accessed 6 September 2017]. 
or EU markets may not have complete control of information and information flow if some trades conducted in its place are reported to a US or European trade repository, whereas the US and EU have access to a large volume of information. How such an information advantage affects regulators and international competition outside of the core markets remains to be seen.

Third, regarding the clearing mandate, if a party chooses to clear a trade in a foreign $\mathrm{CCP}$, the risk associated with the trade may also shift to the location of that CCP. This has two implications. First, it may increase the total risk exposure in the $\mathrm{CCP}$ venue, further burdening the $\mathrm{CCP}$ regulator. Second, the regulator of the trading venue may have to accept that the risk associated with the trade is governed by a foreign institution and hence the law of the clearing venue. This means that transactions conducted in the trading venue may be regulated by the laws of the clearing venue.

For example, an Australian bank conducts a trade with a US bank in Melbourne. If the bank decides to clear the trade in a US-based CCP because the US bank wants to ensure its compliance with US regulations, the US CCP absorbs the risk associated with the trade. There is little problem if the ССР stays safe and sound. However, if the CCP runs into financial problems, the primary regulators are US regulators. For Australian regulators, the failure of the US CCP may mean that the Australian bank faces counterparty risk, which should be resolved by the CCP. However, it is beyond the Australian regulators' jurisdiction to handle a US CCP, which is thus left to the US regulators. In this sense, US regulations have significant effects on a foreign market.

The same might also happen if there is more connection between futures exchanges (e.g. via cross-trading such as the Eurex/KRX link). The Eurex/ KRX link manages potential solvency risk of foreign CCPs by having trades cleared in the home market. For example, a trade conducted by an Eurex member during the trading hours of KRX would be cleared by the clearing arm of Eurex in Europe. In this way, the arrangement is more like an extension of trading hours hosted by another futures exchange. With no local clearing in the host country, regulators in the host country (e.g. South Korea) would have less issue as risks do not stay and home market regulators (e.g. Europe) can still control risk from trading committed in the foreign market. Nonetheless, this would become an issue if any 
trading link between two futures exchanges involve clearing in the host or a third market.

There may also be global competition problems. For the clearing model to work well, there must be sufficient liquidity. Therefore, a large exchange operator or clearing service provider may only get larger with more liquidity and probably a better pool of collateral to draw upon. Moreover, a large trade repository may have more expertise in collecting and packaging data and have a larger volume of data available for analysis. ${ }^{45}$ In fact, some large data repositories have significant operations even outside of their home markets. For example, Singapore's sole trade repository is a subsidiary of the DTCC, ${ }^{46}$ the US giant. Although a trade repository is still locally incorporated and licensed, data may be aggregated across countries and US regulators may still have a say in how to regulate the parent institution in the US. Thus, the extraterritorial effects of US and/or EU regulations can hardly be avoided.

\subsection{POTENTIAL SOLUTIONS}

\section{FOR NON-US AND NON-EU MARKETS}

How can the territorial extension and extraterritorial application of major market regulations, coming from a highly interconnected market with dominant dealers, be addressed? From the angle of Asian regulators, there may be several strategies for negotiating the extraterritoriality of US or EU regulations.

One solution is to require firms to comply with local regulations only if they or a transaction fall within the jurisdiction of local regulators. For example, for mandatory reporting of OTC derivatives, Hong Kong requires traders to report to the Hong Kong Trade Repository. ${ }^{47}$ This approach may ensure local regulators of data completeness. ${ }^{48}$ Nevertheless, some US or European dealers may simply choose to trade in other markets

45 For example, it has been reported that the DTCC, a large trade repository, uses blockchain technology to process over trade information worth over trillions of dollars a year. Murphy H. (2017) Database Move Gives Blockchain its First Big Test Case. Financial Times, 9 January. Available from: https://www.ft.com/content/aeb63b96-d64b-11e6-944b-e7eb37a6aa8e [Accessed 6 September 2017].

46 The company is registered as DTCC Data Repository (Singapore) Pte. Ltd.

47 HK Reporting Rules, footnote 43, rule 20.

48 Hong Kong Securities and Futures Commission. (2013) Consultation Conclusions and Further Consultation on the Securities and Futures (OTC Derivative Transactions - Reporting and Record Keeping Obligations) Rules, p. 59. Hong Kong: SFC. Available from: http://www.sfc.hk/edistri butionWeb/gateway/EN/consultation/doc?refNo=14CP8 [Accessed 6 September2017]. 
to reduce compliance costs and legal risks. If so, this may not be good news for a local regulator aiming to grow its market.

Another solution is to allow substituted compliance in an equivalent jurisdiction with a similar regulatory requirement. In general, substituted compliance means allowing a person to comply with local law by way of complying with the law of a foreign country. In other words, the compliance with foreign law is a substitute for the compliance with local law. The allowance of substituted compliance is built upon equivalent and mutual recognition, so that a local regulator may ensure that the quality of compliance is upheld. This also means that a person cannot substitute his or her local compliance obligation simply by complying with the law of any country of choice. The country must be recognised by the local regulator.

For example, according to Singapore's regulations on trade reporting of OTC derivatives, a person is deemed to have complied with the reporting obligation if any other party (or the principal party, if the specified person is an agent) is incorporated under a foreign law and if that party is required to comply with the reporting law of the foreign country. ${ }^{49}$ Thus, Singapore allows for substituted compliance if the other party to a trade is a foreign person who is obliged to report a trade pursuant to the laws in his or her home country.

Although allowing substituted compliance may help to address market participants' concerns over double compliance, it has its own shortcomings. By allowing substituted compliance, a local regulator may lose a certain degree of control, as it may not be easy to supervise the compliance process. In addition, substituted compliance may mean that the local regulator does not have control of all of the information under its nose. For example, if reporting to a foreign trade repository were allowed, the local regulator would no longer have direct access to information on some trades. Cross-border regulatory cooperation may resolve this problem. For instance, the Monetary Authority of Singapore signed a memorandum of understanding for information sharing with the Australia Securities and Investments Commission in $2014 .^{50}$ However, unless there is a global

49 Securities and Futures Act s 128(1) and (2). Republic of Singapore. Singapore. In English.

50 See the MAS. (2014) ASIC and MAS sign World-First Memorandum of Understanding on Authorities' Access to OTC Derivatives Trade Repository Data. [online] Singapore: MAS. Available from: http://www.mas.gov.sg/News-and-Publications/Media-Releases/2014/ASIC -and-MAS-sign-World-First-Memorandum-of-Understanding.aspx [Accessed 6 September 2017]. 
agreement on mutual (or even multilateral) information sharing, the regulator must sign multiple agreements with foreign regulators to achieve the effect.

Substituted compliance may even have a dire implication for non-US and non-EU regulators. With the US and UK dominating the OTC derivatives market, it is perhaps reasonable to some major Western dealers to choose not to trade in a market if the regulator of that market does not allow substituted compliance of the clearing mandate. However, allowing substituted compliance of the clearing mandate also means that some local trades may be cleared in a foreign CCP. This may affect the volume of OTC derivatives cleared in that market. If the market's regulator has the ambition to grow the clearing business of OTC derivatives, it may be negatively affected.

In addition, that some local trades involving local market participants may be cleared in a foreign CCP implies that the local regulator must depend on the regulations and enforcement of the regulator of the foreign CCP to ensure its solvency and integrity. As a result, substituted compliance of the clearing mandate is often allowed only if the alternative clearing venue is in country recognised by the local regulator based on equivalence and mutual recognition. For example, in Singapore, the law generally allows for substituted compliance of the clearing obligation if the foreign country in question is a "relevant clearing jurisdiction". 51 In Hong Kong, substituted compliance of the clearing mandate is allowed if a trade is cleared by a CCP in that jurisdiction designated by the regulator, with the $\mathrm{CCP}$ being a designated $\mathrm{CCP} .{ }^{52}$ At the moment, Hong Kong's regulators seem to prefer to recognise member states of the OTC Derivatives Regulators Group ${ }^{53}$ as "comparable overseas jurisdictions". ${ }^{4}$ Nevertheless, substituted compliance does not negate that the clearing system and related risk are not fully under the supervision

51 Securities and Futures Act s 129F(1). Republic of Singapore. Singapore. In English.

52 Securities and Futures (OTC Derivative Transactions - clearing and Record Keeping Obligations and Designation of Central Counterparties) Rules (Cap 571AN), rule 11(1). Hong Kong Special Administrative Region of the People's Republic of China. Hong Kong: SFC. In English. ("HK Clearing Rules")

53 OTC Derivatives Regulators Forum. (2017) Authorities Currently Involved in the OTC Derivatives Regulators' Forum. Available from: http://www.otcdrf.org/about/members.htm [Accessed 6 September 2017].

54 Hong Kong Securities and Futures Commission. (2016) Consultation Conclusions and Further Consultation on Introducing Mandatory Clearing and Expanding Mandatory Reporting, paras. [117]-[120]. Hong Kong: SFC. Available from: https://www.sfc.hk/edistributionWeb/ gateway/EN/consultation/conclusion?refNo=15CP4 [Accessed 6 September 2017]. 
of the local regulator. How substituted compliance affects global competition remains to be seen. Whether such mutual information sharing would work also remains to be seen. Only time will reveal the real effects.

A final solution may be to harmonise global financial regulations to reduce differences and extraterritorial effects. Regarding the derivatives market, much like many other international financial regulatory standards (e.g. the Basel Accord), there is no international hard law (i.e. treaties) signed by states to implement a set of rules. Instead, the current method is to implement the regulations through the so-called "soft law approach". In the soft law approach, regulators around the world set international regulatory standards not by negotiating a formal treaty, but through "informal committees of ministry officials, regulators, or private experts". ${ }^{5}$ The most obvious example is the Basel Accord for capital adequacy standards of banks, issued by the Basel Committee on Banking Supervision, which is a kind of transnational regulatory network (TRN) attended by regulators of major world markets. Other examples of TRNs include the Financial Stability Board (FSB), the International Organisation of Securities Commissioners and the International Association of Insurance Supervisors. Together they are responsible for setting standards for many regulatory issues across the three main pillars of the financial market. For example, in addition to OTC derivatives regulation, the FSB is in charge of designating globally and systemically important financial institutions.

Adopting the soft law approach reflects that more cross-border regulatory cooperation is necessary to ensure the solvency and stability of the globalised and well-connected financial market. ${ }^{56}$ Although negotiating a treaty may be time-consuming and ill fitted for the fast-moving financial market, the soft law approach provides speed, flexibility and expertise through the collaboration of specialised regulators. ${ }^{57}$ Nevertheless, whether this approach is sustainable and legitimate is a broad question that is beyond the scope of this article. ${ }^{58}$

55 Gadinis, S. (2015) Three Pathways to Global Standards: Private, Regulator, and Ministry Network. American Journal of International Law, 109, p. 1.

56 Brummer, C. (2012) Soft Law and the Global Financial System: Rule Making in the 21st Century, Cambridge: Cambridge University Press, p. 16.

57 Verdier, P.-H. (2013) The Political Economy of International Financial Regulation. Indiana Law Journal, 88, pp. 1456-1459.

58 See generally Brummer, above note 55; Gadinis, above note 58; Shaffer, G. \& Pollack, M.A. (2010) Hard vs. Soft Law: Alternatives, Complements, and Antagonists in International Governance. Minnesota Law Review, 94, pp. 706-799. 
Regarding OTC derivatives, the three mandates arose through the same approach. They were prescribed by the G20 before the FSB issued a guideline $^{59}$ for each member country to follow. However, not every country has implemented the three mandates at the same pace. From the FSB's periodical progress report, it is clear that several member countries have not fully implemented the three mandates. ${ }^{60}$ After examining the regulatory developments in Hong Kong, Singapore, China and Taiwan, Gao and Chen find significant gaps in the implementation of the three mandates in East Asia outside of Japan. ${ }^{61}$ For example, Hong Kong and Singapore both implemented the reporting mandate first. However, Hong Kong issued its final clearing regulations for OTC derivatives only in September 2016, and Singapore had not even published its final clearing rules by the end of $2016 .^{62}$ China and Taiwan are not even close to implementing any mandate. Even in major markets, there may be some lag. For example, the EU put the trading mandate into regulation only in 2014 through the Markets in Financial Instruments Regulation. ${ }^{63}$

As Gao and Chen argue, the time gap in implementing the three mandates reflects that other concerns and interests underlie the economic functions of the three mandates. For example, the reporting mandate is least controversial, as it tries to enhance market transparency. Furthermore, information sharing is the biggest hurdle to overcome even if a country allows substituted compliance, considering the wide US territorial extension of the DFA. ${ }^{64}$ However, for clearing and trading mandates, other national interests (e.g. competition to become a larger international financial centre) and domestic concerns (e.g. solvency of local financial markets) must be

\footnotetext{
59 Financial Stability Board. (2010) Implementing OTC Derivatives Market Reforms. Basel: FSB. Available from: http://www.fsb.org/2010/10/fsb-report-on-implementing-otc-derivativesmarket-reforms/ [Accessed 6 September 2017].

60 See Financial Stability Board. (2016) Implementation and Effects of the G20 Financial Regulatory Reforms - Dashboard. Basel: FSB. Available from: http://www.fsb.org/wp-content/uploads/ Report-on-implementation-and-effects-of-reforms-dashboard.pdf [Accessed 6 September 2017].

61 See Gao and Chen, above note 15.

62 Ibid.

63 Regulation (EU) No. 600/2014 of the European Parliament and of the Council of 15 May 2014 on markets in financial instruments and amending Regulation (EU) No. 648/2014, art. 28. Official Journal of the European Union (L 173/84) 12 June. Available from: http://eurlex.europa.eu/legal-content/EN/TXT/?uri=CELEX\%3A32014R0600 [Accessed 6 September 2017].

64 See Gao and Chen, above note 15.
} 
considered. This complicates the design and implementation of the two mandates for Asian regulators. ${ }^{65}$

Last, would more harmonisation facilitate more interconnection? It is hard to predict the market and how regulations may evolve in the fast-moving financial market. This article believes that a higher degree of harmonisation of rules governing the derivatives market (no matter they are about exchange trading, clearing or OTC market regulation) should help more interconnection and competition. With rules in different countries more akin to each other, it would facilitate traders to conduct trading in different markets and reduce legal uncertainties and potential extraterritorial effect of national regulations.

\section{CONCLUSION}

There is probably no other corner of the global financial market that is more interconnected and polarised than the derivatives market. The high degree of interconnection also poses problems for regulators, especially in countries that are not major markets. The US, UK and EU dominate the derivatives market. Although Asian markets may have niche products or expertise in specialised products, they fall behind in the OTC markets.

The sheer dominance of Western markets and dealers twists the market and the development of global regulations, granting US and EU regulations significant extraterritorial effects for activities in non-US and non-EU countries. On the private law side, it is through the total dominance of the ISDA master agreement. On the regulatory side, Asian markets are almost forced to accept the regulatory reforms on OTC derivatives, although studies have shown different degrees of implementation due to various national interests and market conditions. Harmonising global regulations at least in major markets may be the solution to reducing the extraterritoriality and territorial extension of the effects of the regulations of major derivatives markets, such as the US, the UK and Europe. Although some international organisations may lead the efforts, there are still some technical differences and uncertainties ahead for regulators in Asia and other developing countries.

65 Ibid. 


\section{LIST OF REFERENCES}

[1] Bank of International Settlement. (2016) Triennial Central Bank Survey of Foreign Exchange and OTC Derivatives Markets in 2016. [online] Basel: BIS. Available from: http://www.bis.org/publ/rpfx16.htm [Accessed 6 September 2017].

[2] Bank of International Settlement. (2013) Triennial Central Bank Survey - Interest Rate Derivatives Market Turnover in 2013: Preliminary Global Results. Basel: BIS, Available from: http://www.bis.org/publ/rpfx13ir.pdf [Accessed 6 September 2017].

[3] Braithwaite, J.P. (2016). The Dilemma of Client Clearing in the OTC Derivatives Markets. European Business Organisation Law Review, 17, p. 355-378.

[4] Brunsden, J. and Stafford, P. (2016) EU and US Strike Derivatives Regulation Deal. Financial Times, 11 February. Available from: https://www.ft.com/content/b7f72edacfef-11e5-92a1-c5e23ef99c77 [Accessed 6 September 2017].

[5] Brummer, C. (2012). Soft Law and the Global Financial System: Rule Making in the $21^{\text {st }}$ Century, Cambridge: Cambridge University Press.

[6] Chamorro-Courtland, C. (2012). The Trillion Dollar Question: Can a Central Bank Bail Out a Central Counterparty Clearing House Which Is "Too Big to Fail"? Brooklyn Journal of Corporate, Financial \& Commercial Law, 6, p. 433.

[7] Chen, C. (2011) Product Due Diligence and the Suitability of Minibonds: Taking the Benefit of Hindsight. Singapore Journal of Legal Studies, 2011, pp. 309-329.

[8] Chen, C. (2010). Trading Risk: the Contractual Nature of Derivative Instruments and Certain Regulatory Issues, VDM Verlag Dr. Müller.

[9] Chon G. (2014) Massad See End to US-EU Clearing Disputes. Financial Times, 31 July. Available from: http://www.ft.com/cms/s/0/c0a04f92-18c3-11e4-a51a-00144feabdc0. html\#axzz3PQyKFc50 [Accessed 6 September 2017].

[10] CME. (2017) CME Group Strategic Partnership with Singapore Exchange. [online] Chicago: CME. Available from: http://www.cmegroup.com/international/partnershipresources/sgx-re-sources.html [Accessed 6 September 2017].

[11] CME. (2017) Eurex/TAIFEX Link. [online] Chicago: CME. Available from: http://www. eurexchange.com/exchange-en/products/eurex-taifex-link [Accessed 6 September 2017].

[12] Cohen, S.S. (1995) Financial Services Regulation: a Mid-Decade Review: Colloquium: The Challenge of Derivatives. Fordham Law Review, 63, p. 1993.

[13] Commission Delegated Regulation (EU) No. 285/2014 of 13 February 2012 supplementing Regulation (EU) No.648/2012 of the European Parliament 
and of the Council with regard to regulatory technical standards on direct, substantial and foreseeable effect of contracts within the Union and to prevent the evasion of rules and obligations. Office Journal of the European Union (L85/1) 12 March. Available from: http://eur-lex.europa.eu/LexUriServ/LexUriServ.do? uri=OJ:L:2014:085:0001:0003:EN: PDF [Accessed 6 September 2017].

[14] Dodd-Frank Wall Street Reform and Consumer Protection Act (Pub. L. 111-203). United States of America. Washington: Government Publishing Office. In English.

[15] Financial Services and Markets Act 2000 (c. 8). United Kingdom of Great Britain and Northern Ireland. London: HMSO. In English.

[16] Flanagan, S.M., 2001. The Rise of a Trade Association: Group Interactions within the International Swaps and Derivatives Association. Harvard Negotiation Law Review, 6, pp. 211-263.

[17] Financial Stability Board. (2016) Implementation and Effects of the G20 Financial Regulatory Reforms - Dashboard. Basel: FSB. Available from: http://www.fsb.org/wpcontent/uploads/Report-on-implementation-and-effects-of-reforms-dashboard.pdf [Accessed 6 September 2017].

[18] Financial Stability Board. (2010) Implementing OTC Derivatives Market Reforms. Basel: FSB. Available from: http://www.fsb.org/2010/10/fsb-report-on-implementing-otcderivatives- market-reforms/ [Accessed 6 September 2017].

[19] G 20. (2009) Leaders' Statement - the Pittsburgh Summit. [online] Available from: http://ec.europa.eu/archives/commission_2010-2014/president/pdf/statement_20090826 _en_2.pdf [Accessed 6 September 2017].

[20] Gadinis, S., 2015. Three Pathways to Global Standards: Private, Regulator, and Ministry Network. American Journal of International Law, 109, pp. 1-57.

[21] Gao, S. \& Chen, C., 2017. Financial Transnationalism and Financial Regulation Change: A Case Study for Derivatives Markets. European Business Organisation Law Review, 19, p. 193-223.

[22] Greenberger, M., 2013. Diversifying Clearinghouse Ownership in Order to Safeguard Free and Open Access to the Derivatives Clearing Market. Fordham Journal of Corporate and Financial Law, 18, pp 245-268.

[23] Henderson, S.K. (2010) Henderson on Derivatives, 2nd Ed., LexisNexis.

[24] Investment ofInsurers, Notice 125. Republic of Singapore. Singapore: MAS. In English.

[25] Hong Kong Securities and Futures Commission. (2016) Consultation Conclusions and Further Consultation on Introducing Mandatory Clearing and Expanding Mandatory 
Reporting. Hong Kong: SFC. Available from: https://www.sfc.hk/edistributionWeb/ gateway/EN/consultation/conclusion?refNo=15CP4 [Accessed 6 September 2017].

[26] Hong Kong Securities and Futures Commission. (2013) Consultation Conclusions and Further Consultation on the Securities and Futures (OTC Derivative Transactions Reporting and Record Keeping Obligations) Rules. Hong Kong: SFC. Available from: http://www.sfc.hk/edistributionWeb/gateway/EN/consultation/doc?refNo=14CP8 [Accessed 6 September 2017].

[27] Hong Kong Securities and Futures Commission. (2011) Consultation Paper on the Proposed Regulatory Regime for the Over-the-Counter Derivatives Market in Hong Kong. Hong Kong: SFC. Available from: http://www.sfc.hk/edistributionWeb/gateway/ EN/consultation/doc?refNo=11CP6 [Accessed 6 September 2017].

[28] Hudson, A.(2012) The Law on Financial Derivatives 5th Ed., London: Sweet \& Maxwell.

[29] Interpretative Guidance and Policy Statement Regarding Compliance with Certain Swap Regulations, 78 FR 45292, 45316-45317. United States of America. Commodities Futures Trading Commission. Washington: CFTC. In English.

[30] Kress, J.C. (2011) Credit Default Swaps, Clearinghouses, and Systemic Risk: What Centralised Counterparties Must Have Access to Central Bank Liquidity? Harvard Journal on Legislation, 48, pp. 49-93.

[31] Monetary Authority of Singapore. (2012) Proposed Regulation of OTC Derivatives. P003-2012. Singapore: MAS. Available from: http://www.mas.gov.sg/News-andPublications/Consultation-Paper/2012/Consultation-Paper-on-Proposed-Regulation-ofOTC-Derivatives.aspx [Accessed 6 September 2017].

[32] Monetary Authority of Singapore. (2014) ASIC and MAS sign World-First Memorandum of Understanding on Authorities' Access to OTC Derivatives Trade Repository Data. [online] Singapore: MAS. Available from: http://www.mas.gov.sg/News-and-Publications/ Media-Releases/2014/ASIC-and-MAS-sign-World-First-Memorandum-ofUnderstanding.aspx [Accessed 6 September 2017].

[33] Murphy H. (2017) Database Move Gives Blockchain its First Big Test Case. Financial Times, 9 January. Available from: https://www.ft.com/content/aeb63b96-d64b-11e6944b-e7eb37a6aa8e [Accessed 6 September 2017].

[34] Nichol, A. (2013) Hedging against the Next Financial Crisis: Proposals for Managing Systemic Risk in Centrally Cleared Derivatives Transactions. Banking and Finance Law Review, 29, pp. 169-184. 
[35] OTC Derivatives Regulators Forum. (2017) Authorities Currently Involved in the OTC Derivatives Regulators' Forum. Available from: http://www.otcdrf.org/about/ members.htm [Accessed 6 September 2017].

[36] Rauterberg, G.V. \& Verstein, A. (2013) Assessing Transnational Private Regulation of the OTC Derivatives Market: ISDA, the BBA, and the Future of Financial Reform. Virginia Journal of International Law, 54, pp. 9-50.

[37] Regulation (EU) No. 600/2014 of the European Parliament and of the Council of 15 May 2014 on markets in financial instruments and amending Regulation (EU) No. 648/2014. Official Journal of the European Union (L 173/84) 12 June. Available from: http://eur-lex. europa.eu/legal-content/EN/TXT/?uri=CELEX\%3A32014R0600

[Accessed 6 September 2017].

[38] Regulation (EU) No. 648/2012 of the European Parliament and of the Council of 4 July 2012 on OTC Derivatives, Central Counterparties and Trade Repositories. Official Journal of the European Union (OJ. L. 201) 27 July. Available from: http://eurlex.europa.eu/legal- content/EN/TXT/?uri=celex\%3A32012R0648

[Accessed 6 September 2017].

[39] Roe, M.J. (2013) Clearinghouse Overconfidence. California Law Review, 101, pp. 1641-1703.

[40] Scott, J. (2014) Extraterritoriality and Territorial Extension of EU Law. The American Journal of Comparative Law, 62, p. 87.

[41] Securities and Futures Act. Republic of Singapore. Singapore. In English.

[42] Securities and Futures (OTC Derivative Transactions - Clearing and Record Keeping Obligations and Designation of Central Counterparties) Rules (Cap 571AN). Hong Kong Special Administrative Region of the People's Republic of China. Hong Kong: SFC. In English.

[43] Securities and Futures (OTC Derivative Transactions - Reporting and Record Keeping Obligations) Rules (Cap 571AL), rule 4(1). Hong Kong Special Administrative Region of the People's Republic of China. Hong Kong: SFC. In English.

[44] Securities and Futures (Reporting of Derivatives Contracts) Regulations 2013 (No.S 668), regulation 2(1). Republic of Singapore. Singapore: MAS. In English.

[45] Shaffer, G. \& Pollack, M.A. (2010) Hard vs. Soft Law: Alternatives, Complements, and Antagonists in International Governance. Minnesota Law Review, 94, pp. 706-799. 
[46] Stafford P. (2016) US Eyes Prize in Brexit Battle Over Derivatives. Financial Times, 20 October. Available from: https://www.ft.com/content/8ae3e610-908b-11e6-a72eb428cb934 b78 [Accessed 6 September 2017].

[47] Stafford P. (2014) Quick View: Clearing up Differences. Financial Times, 16 June. Available from: http://www.ft.com/cms/s/0/3ccba18a-f52d-11e3-91a8-00144feabdc0. html\#axzz3PQyKFc50 [Accessed 6 September 2017].

[48] Verdier, P.-H. (2013) The Political Economy of International Financial Regulation. Indiana Law Journal, 88, pp. 1405-1474.

[49] Wendt, F. (2015) Central Counterparties: Addressing Their Too Important to Fail Nature. [online] IMF. Available from: https://www.imf.org/external/pubs/ft/wp/2015/ wp1521.pdf [Accessed 6 September 2017].

[50] Yadav, Y. (2013) The Problematic Case of Clearinghouses in Complex Markets. Georgetown Law Journal, 101, pp. 387-444.

[51] Financial Times. (2008) Clearing the Way. 17 April. Available from: https://next.ft.com/ content/135b1744-0be2-11dd-9840-0000779fd2ac [Accessed 6 September 2017]. 